DOI: https://doi.org/10.31933/dijms.v3i2 Received: 12 October 2021, Revised: 24 October 2021, Publish: 22 November 2021

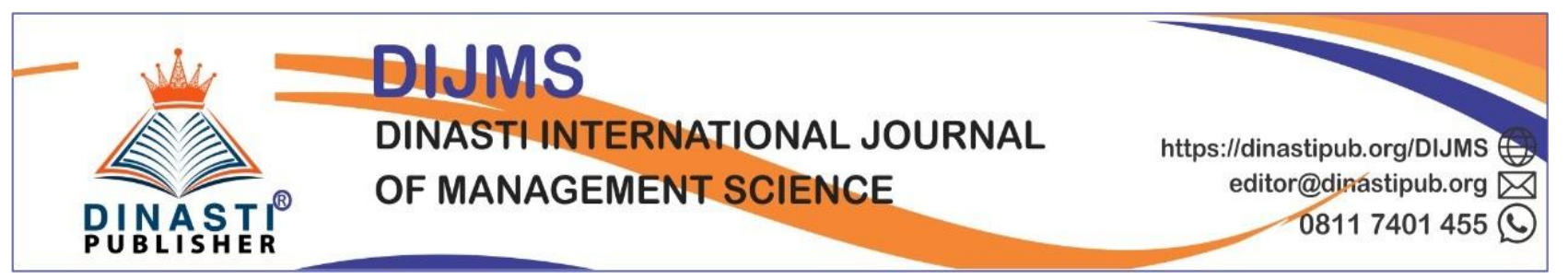

\title{
THE INFLUENCE OF LEADERSHIP, MOTIVATION AND COMPETENCE ON THE PERFORMANCE OF EMPLOYEES OF PT. MODERNLAND REALTY TBK JAKARTA
}

\author{
Irham Habibie ${ }^{1}$ \\ 1) Universitas Mercu Buana, Jakarta, Indonesia, irhamhbb25@gmail.com
}

\section{Corresponding Author: First Author}

\begin{abstract}
This study aims to measure leadership, motivation and competence on the performance of employees of PT Modernland Realty TBK Jakarta. This research is quantitative in nature. The study population was all staff employees. The sampling technique was using nonrandom sampling, namely saturated samples with a total of 89 staff. This study uses multiple linear regression analysis. The results of the t-test state that leadership, motivation and competence partially have a significant positive effect on employee performance. The results of the F-test of leadership leadership, motivation and competence simultaneously have a significant positive effect on employee performance. Suggestions for further research include organizational factors, organizational justice, and job satisfaction as additional independent variables.
\end{abstract}

Keywords: Leadership, Motivation, Competence, Performance

\section{INTRODUCTION}

The existence of human resources in a company plays a very important role, namely as the main mover, and a determinant for the success or progress of a company. The business world is now required to create high employee performance for company development. In improving the performance of its employees, the company takes several ways, namely from leadership to managing human resources so that company goals can be achieved. The existence of a leader is needed in the midst of employees in a company. The ideal leadership is when work goals and decisions are made together within the company and encourage employees to determine and achieve high work performance goals. Arianty (2017:1) states that if the leadership is good, the performance of the employees will be better.

In order to improve employee performance, there are many factors that need to be considered, apart from the leadership aspect, one of the most important factors in improving employee performance is employee motivation and competence. Employees who have high motivation always have the drive to work better in order to achieve special achievements. If there is 
an opportunity for achievement, it will encourage psychologically to increase dedication and utilize its potential in order to improve its performance. Pharisees et.al. (2020:15) states that motivation has a significant positive effect on employee performance.

Competence does not only include skills, knowledge, and attitudes but how to apply them in accordance with performance standards. Competence can deepen and broaden work abilities. The more often someone does the same job, the more skilled and faster he will complete the job. Manik and Syafrina (2018:1) state that competence has a significant positive effect on performance. Good performance can be achieved because there is a mutually supportive relationship between leaders and their subordinates who are committed to the company or organization in achieving its goals. Every company will always try to improve the performance of its employees, with the hope that the company's goals will be achieved. Therefore, employee performance should be considered by company leaders

This research was conducted at PT Modernland Realty Tbk, which is one of the companies in the property sector. Currently PT. Modernland Realty Tbk has recently restructured, which involved a rotation of leadership to the addition of new functions which recruited several new leaders, in this case the old and new leaders, of course, had positive and negative influences. The presence of a new leader has a positive influence such as new expectations for each employee in employee welfare such as salary increases, increased benefits, and health insurance, while other things that employees expect are promotions and permanent employee status, however, have negative impacts such as adaptation. employees to the new policies that have been made and established. Changes in leadership are common and will issue policies that are in accordance with the targets of the company.

\section{LITERATURE REVIEW}

Leadership is defined as a series of abilities and personality traits that exist in a person such as authority, skills, knowledge, vision, and competence where these abilities and personality traits are used to convince the people they lead to want to do the tasks assigned. willingly, enthusiastically, happily, and without coercion (Sagala, 2018:4)

According to Hasibuan (2012: 170) leadership is the way a leader influences the behavior of subordinates, so that they are willing to work together and work productively to achieve organizational goals.

(Path-Goal Theory) from Robert House (in Robbins et.al., 2011:156), namely:

1. Directive Type

a. Leaders who let subordinates know what they are expected to do

b. Leaders who provide special guidance

c. Leaders who ask subordinates to obey procedures and rules

d. Leaders who always make specific work schedules

2. Supportive Type 
a. Leaders who pay attention to employee needs

b. Leaders who create a good work climate

3. Participatory Type

a. The leader considers the ideas and suggestions of subordinates

b. Leaders give freedom of opinion

4. Achievement Oriented Type

a. Demonstrate confidence that employees can achieve high standards

b. Leaders set challenging goals

Catano (in Pribadiyono and Hendarto, 2019:18) describes the definition of competence from various sources, including:

- Competence is a combination of motives, traits, skills, aspects of self-image, social roles, or part of a relevant knowledge. Competence is any individual characteristic that is associated with the success of one's performance

- Characteristic and measurable patterns of knowledge, skills, behaviors, beliefs, values, traits, and underlying motives as well as the ability to quickly do work

- The qualities and skills that employees need to be effective at work

- Skills, knowledge, abilities and behaviors needed to carry out job duties

- Behaviors that must exist to improve basic abilities and work performance to be even higher

- Competence is an individual's basic characteristic that has an effect on effective performance

According to Mangkunegara (2011: 75) the dimensions and performance indicators are as follows:

1. Quality

Quality of work is how well an employee does what he is supposed to do.

2. Quantity

The quantity of work is how long an employee works in one day. This work quantity can be seen from the work speed of each employee.

3. Responsibility

Responsibility for work is an awareness of the employee's obligation to carry out the work given by the company.

\section{Cooperation}

Employees are able to work together with colleagues in completing the tasks assigned by the organization or agency.

5. Initiative

Employees have the ability to do tasks and have initiative. 


\section{RESEARCH METHODS}

To find out the pattern of relationship or influence between independent variables (leadership, motivation and competence) and related variables (performance), the authors used multiple regression analysis techniques. Before the author chooses the analysis, the validity test, reliability test and classical assumption test are carried out first

\section{FINDINGS AND DISCUSSION}

Normality test is used to determine whether the sample from the study population is normally distributed or not. The normality test was carried out after passing the stages of the validity and reliability test. The normality test in this study used a nonparametric test, namely the OneSample Kolmogorov-Smirnov. The results of the normality test can be seen in the table below:

Tabel 1. Normality Test Results

\begin{tabular}{lll}
\hline One-Sample Kolmogorov-Smirnov Test & \\
\hline & & $\begin{array}{l}\text { Unstandardized } \\
\text { Residual }\end{array}$ \\
\hline $\mathrm{N}$ & & 89 \\
Normal Parameters ${ }^{\mathrm{a}, \mathrm{b}}$ & Mean & .0000000 \\
& Std. Deviation & 3.69664569 \\
Most Extreme Differences & Absolute & 0.077 \\
& Positive & 0.077 \\
& Negative & -0.047 \\
Test Statistic & & 0.077 \\
Asymp. Sig. (2-tailed) & & $0.200^{\mathrm{c}, \mathrm{d}}$ \\
\hline
\end{tabular}

a. Test distribution is Normal.

b. Calculated from data.

c. Lilliefors Significance Correction.

$\mathrm{d}$. This is a lower bound of the true significance.

(Source: research data for 2020)

The assessment criteria for the One-Sample Kolmogorov-Smirnov Test is if it is easy. Sig $<0.05$, then the residual data is not normally distributed. If asyimp. Sig $>0.05$, then the residual data is normally distributed. In Table 4.14. shows the result of 0.2 which means it is greater than 0.05 . This means that the residual data is normally distributed.

\section{Multicollinearity Test Results}

The second classic assumption test is the multicollinearity test. The results of this test are seen based on the value of tolerance and VIF (variance inflated factor). The results of the multicollinearity test in this study will be presented in the following table: 
Table 2. Multicollinearity Test Results

\begin{tabular}{llll}
\hline Variabel Independen & $\begin{array}{l}\text { Nilai } \\
\text { Tolerance }\end{array}$ & Nilai VIF & Hasil \\
\hline Leadership $\left(\mathrm{X}_{1}\right)$ & 0.124 & 7.970 & Non Multikolinieritas \\
Motivation $\left(\mathrm{X}_{2}\right)$ & 0.193 & 5.170 & Non Multikolinieritas \\
Competence $\left(\mathrm{X}_{3}\right)$ & 0.239 & 4.192 & Non Multikolinieritas \\
\hline
\end{tabular}

(Source: research data for 2020)

Based on table 4.15. It is known that the tolerance value for each variable is greater than 0.1 and the VIF value for each variable is less than 10 , so it can be concluded that the regression model in this study is free from multicollinearity between independent variables.

\section{Heteroscedasticity Test Results}

The third classic assumption test is the heteroscedasticity test. This test was carried out after passing the normality test and multicollinearity test. The heteroscedasticity test in this study used the glejser method, namely by performing a regression analysis of all independent variables on the absolute residual value. The results of the heteroscedasticity test can be seen in the following table:

Table 3. Heteroscedasticity Test Results

\begin{tabular}{lll}
\hline Variabel Independen & Sig. & Hasil \\
\hline Leadership $\left(\mathrm{X}_{1}\right)$ & 0.838 & Non Heteroskedastisitas \\
Motivation $\left(\mathrm{X}_{2}\right)$ & 0.726 & Non Heteroskedastisitas \\
Competence $\left(\mathrm{X}_{3}\right)$ & 0.273 & Non Heteroskedastisitas \\
\hline
\end{tabular}

(Source: research data for 2020)

Based on Table 4.16. it is known that all variables Sig. on the independent variable is greater than 0.05 . This means that all independent variables do not have symptoms of heteroscedasticity in the residual data or in other words are homoscedasticity.

\section{Hypothesis Test Results}

\section{Multiple Linear Regression Analysis Results}

Linear regression is needed to measure the magnitude of the relationship that occurs between two or more variables. Linear regression is also needed in determining the direction of the strength of the relationship between the independent variable and the dependent variable, the direction can be positive or negative. Regression analysis in this study is used to analyze whether there is an influence between the independent variables, namely Leadership (X1), Motivation (X2) and Competence (X3) on the dependent variable, namely Performance (Y), and how much influence the independent variables have on the dependent variable simultaneously. The following table will present the results of the multiple linear analysis test: 
Table 4. Multiple Linear Regression Analysis Results

Coefficients $^{\mathrm{a}}$

\begin{tabular}{|c|c|c|c|c|c|c|}
\hline \multirow{6}{*}{$\begin{array}{l}\text { Model } \\
1\end{array}$} & & \multicolumn{2}{|c|}{ Unstandardized Coefficients } & \multicolumn{3}{|c|}{$\begin{array}{l}\text { Standardized } \\
\text { Coefficients }\end{array}$} \\
\hline & & B & Std. Error & Beta & $\mathrm{T}$ & Sig. \\
\hline & (Constant) & 6.021 & 2.075 & & 2.902 & 0.005 \\
\hline & $\begin{array}{l}\text { Leadership } \\
\left(\mathrm{X}_{1}\right)\end{array}$ & 0.289 & 0.137 & 0.337 & 2.103 & 0.038 \\
\hline & $\begin{array}{l}\text { Motivation } \\
\left(\mathrm{X}_{2}\right)\end{array}$ & 0.298 & 0.122 & 0.316 & 2.452 & 0.016 \\
\hline & $\begin{array}{l}\text { Competence } \\
\left(\mathrm{X}_{3}\right)\end{array}$ & 0.271 & 0.131 & 0.241 & 2.075 & 0.041 \\
\hline
\end{tabular}

a. Dependent Variable: Kinerja

(Source: research data for 2020)

Based on Table 4.17. in the Unstandardized Coefficients column B shows a constant value $(\alpha)$ of 6.021 and in the next line the coefficient of the independent variable (b) is Leadership of 0.289; Motivation is 0.298 and Competence is 0.271 , the regression equation can be formed as follows:

$$
\begin{aligned}
& \mathrm{Y}=\alpha+\beta 1 \mathrm{X} 1+\beta 2 \mathrm{X} 2+\beta 3 \mathrm{X} 3+\mathrm{e} \\
& 6,021=0,289 \mathrm{X} 1+0,298 \mathrm{X} 2+0,271 \mathrm{X} 3+\mathrm{e}
\end{aligned}
$$

Information :

$$
\begin{aligned}
& Y=\text { Performance } \\
& \alpha=\text { Constant Value } \\
& X 1=\text { Leadership } \\
& \beta 1=\text { Estimated Coefficient X1 } \\
& X 2=\text { Motivation } \\
& \beta 2=\text { Estimated Coefficient X1 } \\
& X 3=\text { Competence } \\
& \beta 3=\text { Estimated Coefficient X1 } \\
& \mathrm{e}=\text { error }
\end{aligned}
$$

Based on the regression equation that has been described previously, it can be explained as follows:

1) This constant $(\alpha)$ indicates that if all the independent variables have a value of zero (0) then the value of the dependent variable (Beta) is 6.021 .

2) Constant value of 6.021 indicates that if the variables of Leadership (X1), Motivation (X2), and Competence (X3) are constant, then Performance (Y) is 6.021.

3) Leadership (X1) on Performance (Y). Leadership variable regression coefficient (X1) is 0.289 and is positive. This indicates that leadership has a direct relationship with performance. This also means that for every one unit increase in the value of Leadership, the value of the 
Performance variable (Y) will increase by 0.289 with the assumption that the value of the Work Motivation and Competence variables in the regression model is fixed.

4) Motivation (X2) on Performance (Y). Motivation variable regression coefficient (X2) is 0.298 and is positive. This shows that motivation has a direct relationship with performance. This also means that for every one unit increase in the value of Motivation, the value of the Performance variable (Y) will increase by 0.298 with the assumption that the value of the Leadership and Competence variables in the regression model is fixed.

5) Competence (X3) on Performance (Y). The regression coefficient of the Competency variable (X3) is 0.271 and is positive. This indicates that competence has a direct relationship with performance. This also means that for every one unit increase in the value of Competence, the value of the Performance variable (Y) will increase by 0.271 with the assumption that the value of the Leadership and Motivation variable in the regression model is fixed.

\section{F Test Results}

The $\mathrm{F}$ test is also known as the simultaneous test or ANOVA. The F test was conducted to determine whether all the independent variables in the regression model have a joint effect on the dependent variable. The results of the F test using SPSS 25 will be presented in the following table:

Table 5. F Test Result

\section{ANOVA $^{\mathrm{a}}$}

\begin{tabular}{lllllll}
\hline Model & & Sum of Squares & Df & Mean Square & F & Sig. \\
\hline 1 & Regression & 3189.553 & 3 & 1063.184 & 75.150 & $.000^{\mathrm{b}}$ \\
& Residual & 1202.537 & 85 & 14.147 & & \\
& Total & 4392.090 & 88 & & & \\
\hline
\end{tabular}

a. Dependent Variable: Performance

b. Predictors: (Constant), Leadership, Motivation, Competence

(Source: research data for 2020)

Based on Table 4.18. It is known that the result of the value of Sig. i.e. 0.000 and less than 0.05. This indicates that the variables of Leadership, Motivation, and Competence together have a significant effect on performance (H4 is accepted).

\section{T Test Result}

The t-test was conducted to find out how much influence the independent variable (independent) independently has on the dependent variable (dependent). This t-test is also intended to estimate the extent of the contribution of changes that occur in each independent variable to the magnitude of the dependent variable. The criteria for making decisions from the t-test are as follows:

- If the value of $t$ count $>t$ table and the value of sig. $<0.05$ then Ha is accepted

- If the value of $t$ count $<t$ table and the value of sig. $>0.05$ then Ha is rejected 
The results of the t test can be seen in the following table:

Table 6. T Test Result

Coefficients $^{\mathbf{a}}$

\begin{tabular}{|c|c|c|c|c|c|c|}
\hline \multirow{6}{*}{$\begin{array}{l}\text { Model } \\
1\end{array}$} & & \multicolumn{2}{|c|}{ Unstandardized Coefficients } & \multicolumn{2}{|l|}{$\begin{array}{l}\text { Standardized } \\
\text { Coefficients }\end{array}$} & \multirow[b]{2}{*}{ Sig. } \\
\hline & & B & Std. Error & Beta & $\mathrm{T}$ & \\
\hline & (Constant) & 6.021 & 2.075 & & 2.902 & 0.005 \\
\hline & $\begin{array}{l}\text { Leadership } \\
\left(\mathrm{X}_{1}\right)\end{array}$ & 0.289 & 0.137 & 0.337 & 2.103 & 0.038 \\
\hline & $\begin{array}{l}\text { Motivation } \\
\left(\mathrm{X}_{2}\right)\end{array}$ & 0.298 & 0.122 & 0.316 & 2.452 & 0.016 \\
\hline & $\begin{array}{l}\text { Competence } \\
\left(\mathrm{X}_{3}\right)\end{array}$ & 0.271 & 0.131 & 0.241 & 2.075 & 0.041 \\
\hline
\end{tabular}

b. Dependent Variable: Employee Performance

(Sumber: data penelitian tahun 2020)

Based on Table 4.19. the following conclusions can be drawn:

1. H1: Leadership variable has a t value of $2.103>1.662$ ( $\mathrm{t}$ table) and has a Sig value. 0.038 is less than 0.05. This means that leadership has a significant influence on performance.

2. H2: Motivation variable has a t value of $2.452>1.662$ ( $\mathrm{t}$ table) and has a Sig value. 0.016 is less than 0.05 . This means that motivation has a significant influence on performance.

3. H3: Competency variable has a t-count value of $2.075>1.668$ ( $t$ table) and has a Sig value. 0.041 is less than 0.05 . This means that competence has a significant influence on performance.

4. The highest value on standardized coefficients beta is in the Leadership variable, which is 0.337 . This shows that the variable that has the greatest influence on performance is leadership

\section{Coefficient of Determination Test Results}

The coefficient of determination test is carried out to find out how much contribution or contribution the independent variable makes to the dependent variable. The results of the determination test can be seen in the following table:

\section{Coefficient of Determination Test Results}

\section{Model Summary}

\begin{tabular}{lllll}
\hline Model & $\mathrm{R}$ & $\mathrm{R}$ Square & $\begin{array}{l}\text { Adjusted } \\
\text { Square }\end{array}$ & $\begin{array}{l}\mathrm{R} \\
\text { Std. Error of the } \\
\text { Estimate }\end{array}$ \\
\hline 1 & $0.852^{\mathrm{a}}$ & 0.726 & 0.717 & 3.761 \\
\hline a. Predictors: (Constant), Leadership , Motivation, Competence
\end{tabular}


(Source: research data for 2020)

Based on Table 4.20. It is known that the $\mathrm{R} 2$ value is 0.726 , which means that the Leadership, Motivation, and Competence variables contribute $72.6 \%$ to the Performance variable while the remaining $27.4 \%$ can be explained by other variables.

\section{InterDimensional Correlation Test Results}

The correlation test between dimensions was carried out to determine the magnitude of the relationship between each dimension of all independent variables and each dimension of the dependent variable. The results of the correlation test between dimensions using the two-tailed Pearson's Correlation method and will be described in the following table:

Table 5. Inter-Dimensional Correlation Matrix

\begin{tabular}{|c|c|c|c|c|c|}
\hline \multirow[t]{2}{*}{ Variabel } & \multirow[b]{2}{*}{ Dimension } & \multicolumn{4}{|c|}{ Performance } \\
\hline & & Quality & Quantity & Punctuality & Presence \\
\hline \multirow[t]{3}{*}{ Leadership } & $\begin{array}{l}\text { Interpersonal } \\
\text { Role }\end{array}$ & 0.667 & 0.761 & 0.722 & 0.772 \\
\hline & $\begin{array}{l}\text { Informational } \\
\text { role }\end{array}$ & 0.690 & 0.771 & 0.712 & 0.755 \\
\hline & $\begin{array}{l}\text { Decision- } \\
\text { making role }\end{array}$ & 0.656 & 0.744 & 0.719 & 0.725 \\
\hline \multirow[t]{3}{*}{ Motivation } & $\begin{array}{l}\text { Need for } \\
\text { achievement }\end{array}$ & 0.669 & 0.770 & 0.755 & 0.737 \\
\hline & $\begin{array}{ll}\text { Need } & \text { for } \\
\text { affiliation } & \\
\end{array}$ & 0.680 & 0.713 & 0.731 & 0.708 \\
\hline & Need for power & 0.570 & 0.689 & 0.634 & 0.708 \\
\hline \multirow[t]{4}{*}{ Competence } & Knowledge & 0.574 & 0.754 & 0.637 & 0.738 \\
\hline & Skills & 0.653 & 0.703 & 0.634 & 0.638 \\
\hline & Behavior & 0.647 & 0.732 & 0.646 & 0.673 \\
\hline & Experience & 0.541 & 0.680 & 0.551 & 0.678 \\
\hline
\end{tabular}

Based on Table 4.21. on the Leadership variable, the Interpersonal Role dimension has the strongest relationship with the Attendance dimension on the Performance variable of 0.772 while the weakest relationship is the Decision Maker's Role dimension on the Quality dimension of 0.656. In the Motivation variable, the dimension that has the strongest relationship is the Dimension Need for Achievement on the Quantity dimension on the Performance variable at 0.770 while the weakest relationship is the Dimension Need for Power to the Quality dimension at 0.570. In the Competency variable, the dimension with the strongest relationship is Knowledge to the Quantity dimension in the Performance variable at 0.754 while the weakest relationship is the Experience dimension to the Quality dimension at 0.541 . 


\section{CONCLUSION AND RECOMMENDATION}

\section{Conclusion}

Based on the results of data processing that has been described in the previous chapter regarding "The Influence of Leadership, Motivation and Competence on Employee Performance at PT. Modernland Realty Tbk jakarta", the following conclusions can be drawn:

1. Leadership has a significant positive effect on performance. The Interpersonal Role dimension correlates the most with the Presence dimension.

2. Motivation has a significant positive effect on performance. The Achievement Needs dimension has the highest correlation with the Quantity dimension.

3. Competence has a significant positive effect on performance. The Knowledge dimension has the highest correlation with the Quantity dimension.

4.Leadership, Motivation and Competence simultaneously have a significant effect on performance.

\section{Recommendation}

Based on the research results and conclusions that have been described previously, the researchers provide suggestions for company leaders and researchers who will conduct further research as follows:

1. Based on the pre-research survey, further researchers are expected to include the variables of Organizational Commitment, Job Satisfaction and Organizational Justice as variables that affect performance.

2. The company should simultaneously improve the leadership, work motivation and competence of its staff to be more effective in improving performance. In this case, leadership is a priority to be improved.

3. The company is expected to further enhance the role of the leader's ability in managing employees, identifying problems, being objective, appearing at various events, as a mover and liaison through leadership training.

4. The company is expected to further increase the need for achievement of its staff by providing salary bonuses for employees who excel and work beyond work standards.

5. The company is expected to provide training related to job duties and responsibilities in order to increase employee knowledge and improve employee performance.

\section{BIBLIOGRAPHY}

Arianty, N. (2017). Pengaruh Kepemimpinan Terhadap Kinerja Karyawan. Kumpulan Jurnal Dosen Universitas Muhammadiyah Sumatera Utara, 4(2).

Farisi, S., Irnawati, J., \& Fahmi, M. (2020). Pengaruh Motivasi dan Disiplin Kerja Terhadap Kinerja Karyawan. Jurnal Humaniora: Jurnal Ilmu Sosial, Ekonomi Dan Hukum, 4(1), 15-33. 
Manik, S., \& Syafrina, N. (2018). Pengaruh Kompetensi Terhadap Kinerja Dosen Sekolah Tinggi Ilmu Ekonomi Riau. Jurnal Ilmiah Ekonomi Dan Bisnis (JIEB), 15(1), 16.

Sagala, H. S., \& Sos, S. (2018). Pendekatan \& Model Kepemimpinan. Prenada Media.

Hasibuan, M. S. (2012). Manajemen sumber daya manusia Jakarta: Bumi Aksara.

Robbins, S. P., Coulter, M., Sidani, Y., Jamali, D., \& Robbins, S. P. (2011). Management (Arab World Editions). Pearson Education UK.

Pribadiyono, I., \& Hendarto, W. (2019). Kompetensi Kerja Perusahaan Perkapalan. Jakad Media Publishing.

Mangkunegara, A. P. (2011). Manajemen Sumber Daya Manusia Perusahaan, edisi 10. Remaja Rosdakarya, Bandung. 